\title{
ORIGINAL ARTICLE \\ Live-cell imaging to compare the transfection and gene silencing efficiency of calcium phosphate nanoparticles and a liposomal transfection agent
}

\author{
S Chernousova and M Epple
}

The processing of DNA (for transfection) and short interfering RNA (siRNA; for gene silencing), introduced into HeLa cells by tripleshell calcium phosphate nanoparticles, was followed by live-cell imaging. For comparison, the commercial liposomal transfection agent Lipofectamine was used. The cells were incubated with these delivery systems, carrying either enhanced green fluorescent protein (eGFP)-encoding DNA or siRNA against eGFP. In the latter case, HeLa cells that stably expressed eGFP were used. The expression of eGFP started after $5 \mathrm{~h}$ in the case of nanoparticles and after $4 \mathrm{~h}$ in the case of Lipofectamine. The corresponding times for gene silencing were $5 \mathrm{~h}$ (nanoparticles) and immediately after incubation (Lipofectamine). The expression of eGFP was notably enhanced 2-3 h after cell division (mitosis). In general, the transfection and gene silencing efficiencies of the nanoparticles were lower than those of Lipofectamime, even at a substantially higher dose (factor 20) of nucleic acids. However, the cytotoxicity of the nanoparticles was lower than that of Lipofectamine, making them suitable vectors for in vivo application.

Gene Therapy (2017) 24, 282-289; doi:10.1038/gt.2017.13

\section{INTRODUCTION}

The delivery of nucleic acids across the cell membrane in gene therapy is a hot topic in biomedical research (gene therapy). ${ }^{1-10}$ As nucleic acids alone are not able to penetrate the cell membrane, they must be transported with a suitable carrier. ${ }^{11}$ Different strategies have been developed to address this problem, ranging from physical methods like electroporation ${ }^{12}$ over viral transduction ${ }^{13}$ to various kinds of nanosystems. Among the nanosystems, dendrimers, liposomes, polymeric and inorganic nanoparticles have been established. ${ }^{3,5-7,11,14-17}$ Typical nanoparticles for transfection comprise gold, ${ }^{18-20}$ iron oxide, ${ }^{21}$ silica, ${ }^{22}$ carbon nanotubes ${ }^{23}$ and many different polymers. ${ }^{2,24,25}$

Calcium phosphate nanoparticles for transfection were first proposed by Maitra, ${ }^{26}$ based on the classical calcium phosphate transfection method by Graham and van der Eb from $1973 .{ }^{27}$ They have gained some attention because of their inherent biocompatibility, their easy preparation and loading with biomolecules, their biodegradation/dissolution after cellular uptake in the lysosome. ${ }^{28-42}$ This is an advantage compared to non-biodegradable nanoparticles, for example, gold or carbon nanotubes. We have introduced the possibility to prepare them in a multishell manner that permits to add a number of biomolecules to the same nanoparticle below a protecting outer shell, ${ }^{43,44}$ including a subsequent covalent functionalization with antibodies. $^{45}$

It has been demonstrated for a number of cell lines ${ }^{46}$ that the transfection efficiency of calcium phosphate nanoparticles was lower than that of optimized cationic liposomal agents ${ }^{47-49}$ like Lipofectamine. ${ }^{50,51}$ However, such cationic transfection agents are usually associated with a significant degree of cytotoxicity that restricts their application in vivo. ${ }^{46,52}$ On the other hand, almost all cell types take up nanoparticles, ${ }^{46}$ but this does not always lead to an efficient processing of the transported nucleic acid. It has also been suggested that a successful transfection depends on the cell division, ${ }^{53,54}$ although it has recently been demonstrated that a transfection can occur without mitosis. ${ }^{55,56}$

To elucidate the intracellular processing of nucleic acids that are taken up by cells with the help of nanoparticles or liposomes, we have carried out live-cell imaging studies and monitored the time course of transfection and gene silencing, both with nanoparticles and Lipofectamine. This powerful in situ method ${ }^{57}$ allows a time-dependent insight into transfection and gene silencing.

\section{RESULTS AND DISCUSSION}

Triple-shell nanoparticles of calcium phosphate-nucleic acidcalcium phosphate-poly(ethyleneimine), denoted as CaP/DNA/ $\mathrm{CaP} / \mathrm{PEI}$ and $\mathrm{CaP} / \mathrm{siRNA} / \mathrm{CaP} / \mathrm{PEI}$ in the following, were prepared and purified from dissolved nucleic acids, PEI and synthesis byproducts. Figure 1 shows scanning electron micrographs of both kinds of particles. The particles are mostly spherical with a typical diameter of $60 \mathrm{~nm}$.

The particles were well dispersable in water as indicated by dynamic light scattering and nanoparticle tracking analysis. The higher hydrodynamic diameter in dispersion in comparison to the diameter of the solid core indicates a moderate degree of agglomeration. The particles carried a positive charge as shown by the zeta potential due to the external layer of PEl. Under the assumption of spherical particles, it was possible to compute the particle concentration. The analytical data of both kinds of nanoparticles are given in Table 1. Note that it is not possible to exactly determine the position of the nucleic acid within the multishell nanoparticle, but clear evidence comes from colloid-

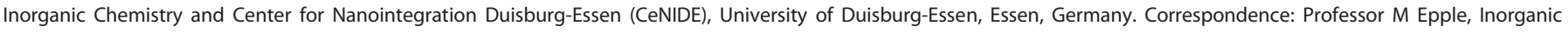
Chemistry, University of Duisburg-Essen, Universitaetsstrasse 5-7, D-45117 Essen, Germany. 

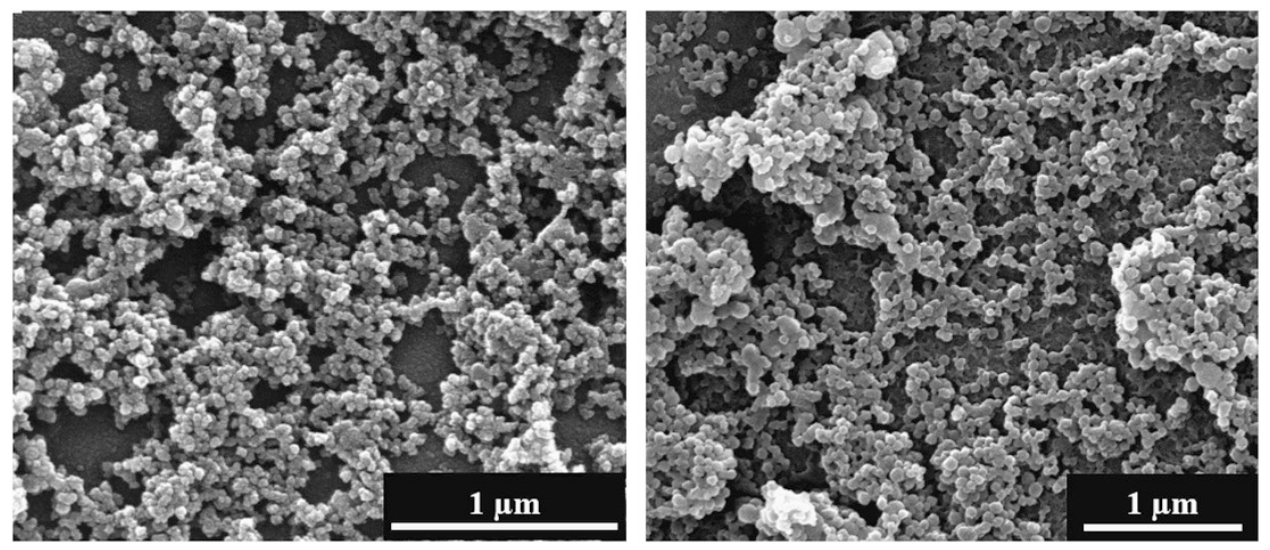

Figure 1. Scanning electron micrographs of CaP/DNA/CaP/PEI nanoparticles (left) and of CaP/siRNA/CaP/PEI nanoparticles (right).

\begin{tabular}{|c|c|c|}
\hline Sample & $\begin{array}{c}\text { CaP/DNA/ } \\
\text { CaP/PEI }\end{array}$ & $\begin{array}{c}\text { CaP/siRNA/ } \\
\text { CaP/PEI }\end{array}$ \\
\hline Diameter by SEM (nm) & 60 & \\
\hline$V$ (one nanoparticle; $\mathrm{m}^{3}$ ) & $1.13 \times 10^{-22}$ & $1.13 \times 10^{-22}$ \\
\hline m (one nanoparticle; kg) & $3.55 \times 10^{-19}$ & $3.55 \times 10^{-19}$ \\
\hline$w\left(\mathrm{Ca}^{2+}\right)$ by AAS $\left(\mathrm{kg} \mathrm{m}^{-3}=\mathrm{mg} \mathrm{ml}^{-1}\right)$ & 0.092 & 0.048 \\
\hline$w\left(\mathrm{Ca}_{5}\left(\mathrm{PO}_{4}\right)_{3} \mathrm{OH} ; \mathrm{kg} \mathrm{m}^{-3}=\mathrm{mg} \mathrm{ml}^{-1}\right)$ & 0.23 & 0.12 \\
\hline$N\left(\right.$ nanoparticles; $\mathrm{m}^{-3}$ ) & $6.48 \times 10^{17}$ & $3.38 \times 10^{17}$ \\
\hline$N\left(\right.$ nanoparticles; $\mathrm{ml}^{-1}$ ) & $3.38 \times 10^{11}$ & $3.38 \times 10^{11}$ \\
\hline Hydrodynamic diameter by DLS $(\mathrm{nm})$ & 147 & 209 \\
\hline Hydrodynamic diameter by NTA $(\mathrm{nm})$ & 157 & 230 \\
\hline PDI by DLS & 0.4 & 0.3 \\
\hline Zeta potential by DLS (mV) & +19 & +22 \\
\hline $\begin{array}{l}\text { Concentration of nucleic acid } \\
\left(\mathrm{kg} \mathrm{m}^{-3}=\mathrm{mg} \mathrm{ml}^{-1}\right)\end{array}$ & 0.02 & 0.02 \\
\hline Concentration of PEI $\left(\mathrm{kg} \mathrm{m}^{-3}=\mathrm{mg} \mathrm{ml}^{-1}\right)$ & 0.03 & 0.01 \\
\hline \multicolumn{3}{|c|}{$\begin{array}{l}\text { Abbreviations: DLS, dynamic light scattering; NTA, nanoparticle tracking } \\
\text { analysis; PDI, polydispersity index; PEI, poly(ethyleneimine); SEM, Scanning } \\
\text { electron microscopy; siRNA, short interfering RNA. The particle properties } \\
\text { were computed based on the solid particle diameter by SEM. Al } \\
\text { concentrations refer to the original nanoparticles' dispersions, which were } \\
\text { later added to the cell and thereby diluted } 1: 7 \text { (transfection) and 1:5 (gene } \\
\text { silencing). For the actual concentrations of particles and nucleic acids in } \\
\text { each well, see text. }\end{array}$} \\
\hline
\end{tabular}

chemical data where the surface charge of nanoparticles was measured after each shell. ${ }^{58}$

For transfection, the stock solution (Table 1) was diluted 1:7. This gives a DNA concentration of $2.8 \mu \mathrm{g} \mathrm{ml} \mathrm{m}^{-1}$ and a particle concentration of $4.8 \times 10^{10} \mathrm{ml}^{-1}$. Clearly, the number of nanoparticles strongly exceeded the number of cells $\left(1.5 \times 10^{4} \mathrm{~cm}^{-2}\right)$. The concentration of DNA in the transfection with Lipofectamine was $0.14 \mu \mathrm{g} \mathrm{ml}^{-1}$.

First, the uptake of both kinds of nanoparticles by HeLa cells was studied. For this, the particles were fluorescently labeled with PEI-FITC (fluorescein isothiocyanate). After $4 \mathrm{~h}$, many cells had taken up the particles (Figure 2).

The transfection with enhanced green fluorescent protein (eGFP)-encoding DNA was carried out both with nanoparticles and with Lipofectamine and followed by live-cell imaging. The high degree of transfection is shown in Figure 3. After 72, a high number of cells was transfected with both nanoparticles and Lipofectamine.

The microscopic images were manually analyzed to quantify both the transfection efficiency and the cell viability. The ratio of the number of transfected (green) cells to the total number of cells gave the transfection efficiency. As the images always showed the same part of the cell culture, we were able to assess the cell viability by counting the total number of cells in the images. As absolute cell numbers were counted, this gave a better indication of the cell viability than relative assays like the MTT test. As control, HeLa cells were cultivated under the same conditions, but without transfection agent.

Figure 4 shows the results for the transfection with Lipofectamine. The expression of eGFP started after $\sim 4 \mathrm{~h}$ with a steep increase, reaching almost $100 \%$ after $24 \mathrm{~h}$. The number of cells first increased but then dropped to $\sim 50 \%$ of the initial value where it remained. In the control, the number of cells steadily increased to more than $400 \%$ of the initial value. In total, after transfection with Lipofectamine for $72 \mathrm{~h}, 50 \%$ of the original cell number are still there, and all of them are transfected.

The transfection with nanoparticles showed a completely different picture (Figure 5). The expression of eGFP started slightly later $(5 \mathrm{~h}$ ) but with a gentler slope, reaching $\sim 35 \%$ after $30 \mathrm{~h}$. The transfection was shorter-lived than with Lipofectamine, dropping after $\sim 50 \mathrm{~h}$. However, the number of cells increased more steadily than with Lipofectamine with a plateau at the highest percentage of transfected cells. After $72 \mathrm{~h}$, the number of cells was $\sim 250 \%$ of the original value with $20 \%$ transfected cells. If we compare this to $100 \%$ of initially present cells, this corresponds to $50 \%$ transfected cells and $200 \%$ non-transfected cells after $72 \mathrm{~h}$. Interestingly, this is the same total number of transfected cells as with Lipofectamine, but accompanied by the fourfold amount of untransfected cells.

A closer inspection of the images indicated that the transfection was associated with the cell division. Many examples were found where the expression of eGFP occurred 2-3 h after cell division, both for Lipofectamine and nanoparticles (Figure 6). This was also reported for the transfection of HeLa cells with Lipofectamine ${ }^{55}$ and also by us for the transfection of HeLa cells from a nanoparticle-coated surface. ${ }^{59}$

Gene silencing by siRNA occurs in the cytoplasm, in contrast to transfection with DNA that has to enter the cell nucleus. Consequently, gene silencing is typically easier than transfection. We have compared the transfection efficiency of HeLa-eGFP cells both with nanoparticles and with Lipofectamine. In this case, the intracellular biosynthesis of eGFP is blocked and the green fluorescence is gradually vanishing.

For gene silencing, the stock solution (Table 1) was diluted 1:5. This gives an siRNA concentration of $4 \mu \mathrm{g} \mathrm{ml}^{-1}$ and a particle concentration of $6.8 \times 10^{10} \mathrm{ml}^{-1}$. Again, the number of nanoparticles strongly exceeded the number of cells $\left(1.4 \times 10^{4} \mathrm{~cm}^{-2}\right)$. The concentration of siRNA during the transfection with Lipofectamine was $0.2 \mathrm{\mu g} \mathrm{ml}^{-1}$. 

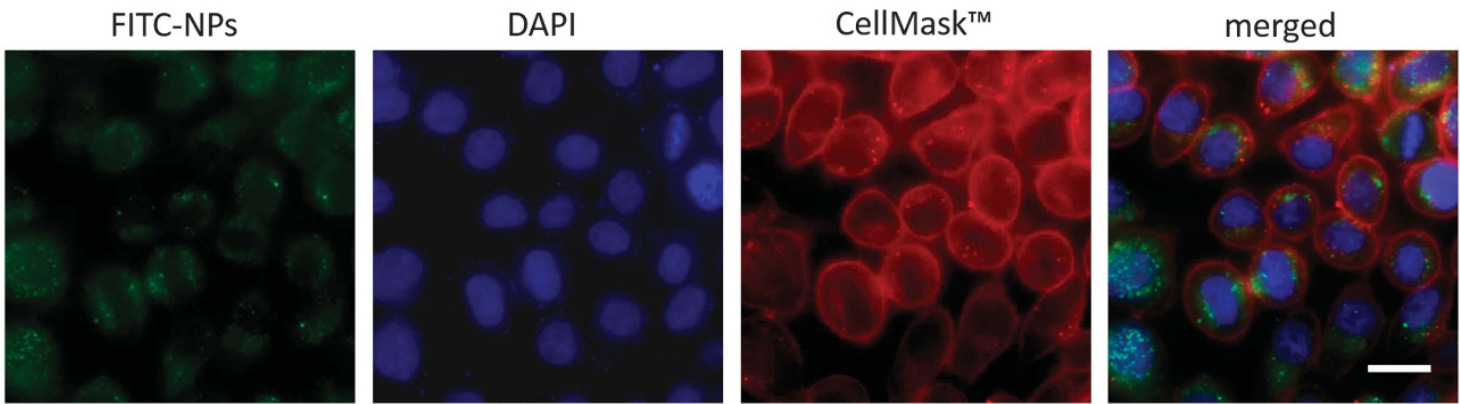

Figure 2. Localization of CaP/DNA/CaP/PEI-FITC nanoparticles after $4 \mathrm{~h}$ incubation of HeLa cells. Green represents CaP/DNA/CaP/PEI-FITC nanoparticles, blue represents nuclei stained by 4,6-diamidino-2-phenylindole (DAPI) and red represents the cell membrane. Scale bar $20 \mu \mathrm{m}$.
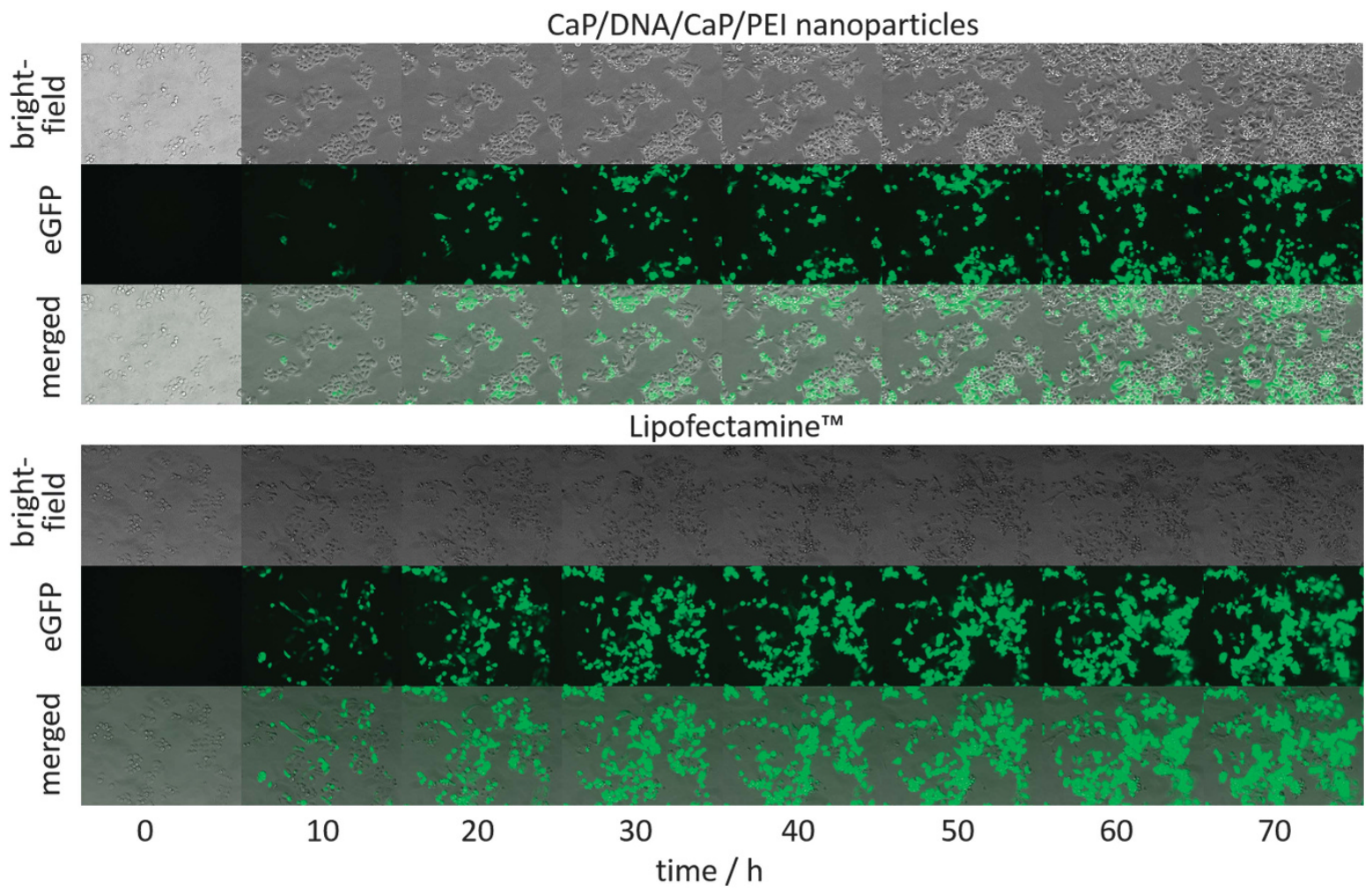

Figure 3. Live-cell imaging microscopy of HeLa cells during transfection with CaP/DNA/CaP/PEI nanoparticles and Lipofectamine over $72 \mathrm{~h}$. The increasing number of green fluorescent cells indicates the successful transfection by both Lipofectamine and DNA-loaded nanoparticles.

Figure 7 shows corresponding data recorded over $72 \mathrm{~h}$. It must be noted that the HeLa-eGFP cells are continuously dividing, that is, the number of green fluorescent cells is steadily increasing in the control.

Lipofectamine caused a continuous increase in the genesilencing efficiency up to $72 \mathrm{~h}$, when almost all cells were silenced (Figure 8). Gene silencing started almost immediately after incubation. The rate of cell proliferation was about half of the rate of control cells, that is, after $72 \mathrm{~h}$, the cell number had increased by a factor of four with Lipofectamine and by a factor of eight in the control. The HeLa-eGFP cells were dividing about two times faster than the HeLa cells. Altogether, the silencing with Lipofectamine resulted in $400 \%$ of silenced cells, compared to the original cell population.

Nanoparticles also showed a steady increase of gene silencing, starting $\sim 5 \mathrm{~h}$ after incubation (Figure 9). After $72 \mathrm{~h}$, the genesilencing efficiency was $\sim 35 \%$. The cell proliferation was almost not constrained by the presence of nanoparticles, leading to $700 \%$ of the original cell number after $72 \mathrm{~h}$. Taken together, after $72 \mathrm{~h}$ incubation with nanoparticles, eGFP was silenced in $\sim 240 \%$ of the original cell number, accompanied by $\sim 460 \%$ of nonsilenced cells.

If we consider the cell proliferation in more detail, two separate effects have to be distinguished. As control, we always used untreated cells. If the cell proliferation in the presence of transfection agents was lower than in the control, this would be because of two effects: first, the effect of the transfection agent (that is, calcium phosphate nanoparticle or Lipofectamine), and second, the effect of the transfection itself (that is, the introduction and intracellular processing of the nucleic acid). It is not easy to separate these effects; however, in the light of earlier data on the effects of calcium phosphate nanoparticles (only cytotoxic at high doses ${ }^{60-62}$ ) and Lipofectamine (a moderate degree of cytotoxicity ${ }^{63,64}$ ), also reported earlier in our comprehensive 


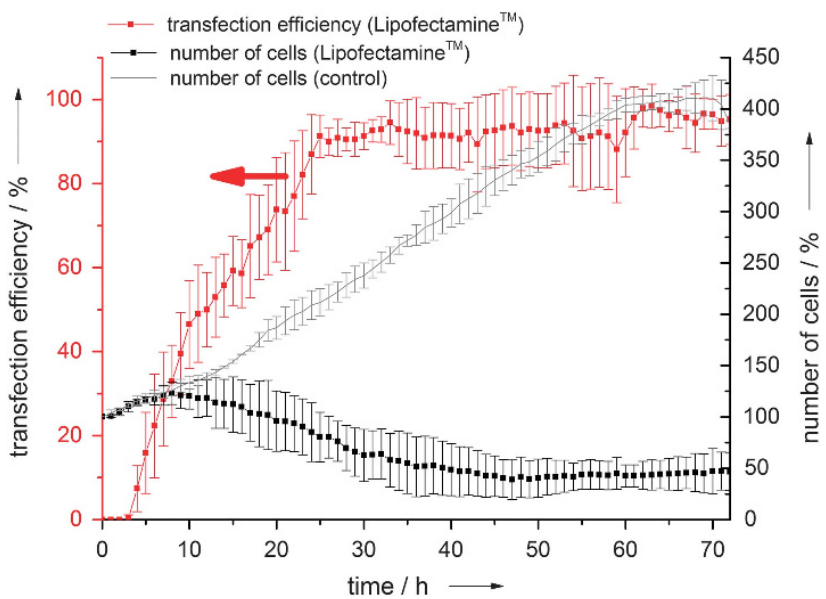

Figure 4. Transfection efficiency and relative number of HeLa cells during $72 \mathrm{~h}$ transfection with Lipofectamine. The relative number of the cells at the first time point $(0 \mathrm{~h})$ corresponds to $100 \%$. The control represents untreated HeLa cells.

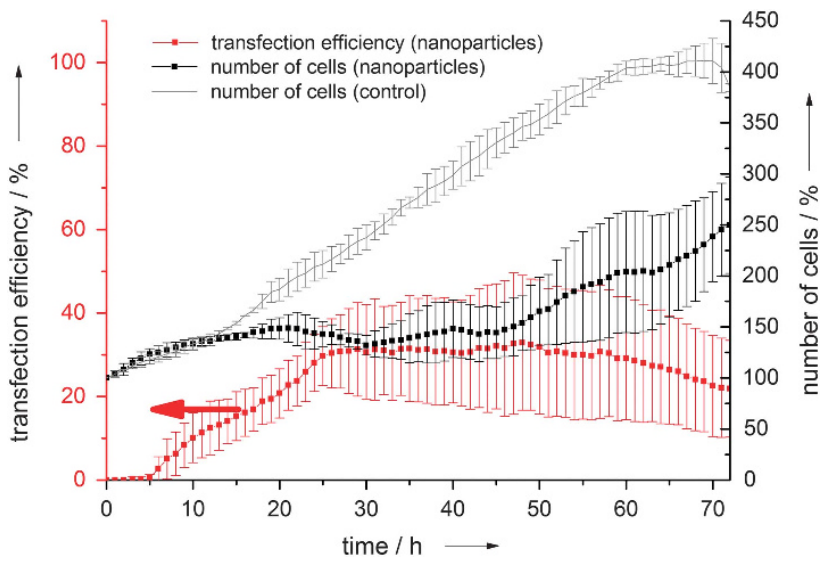

Figure 5. Transfection efficiency and relative number of HeLa cells during $72 \mathrm{~h}$ transfection with CaP/DNA/CaP/PEl nanoparticles. The relative number of the cells at the first time point $(0 \mathrm{~h})$ corresponds to $100 \%$. The control represents untreated HeLa cells.

study with 10 different cell lines and these two transfection agents, ${ }^{46}$ it is highly likely that the processing of the nucleic acid does not have a significant role during the presented live-cell imaging experiments.

The gene-silencing efficiency probes the intracellular degradation of the corresponding protein (here, eGFP) because it essentially prevents the biosynthesis of the protein. This is a completely different mechanism than transfection where the biosynthesis of a specific protein is turned on. It is therefore not surprising that it is slower than the transfection. Of course, this will depend on the lifetime of a specific protein inside a cell. Bartlett and Davis ${ }^{65}$ have presented a kinetic model for the underlying processes. Both transfection and gene silencing will be transient, that is, after DNA or siRNA are consumed. Bartlett and Davis ${ }^{66}$ have also shown that gene silencing lasts $\sim 1$ week in rapidly dividing cells and $\sim 1$ month in slowly dividing cells. This has been ascribed to the dilution of siRNA by cell division, demonstrating a remarkable stability of siRNA in the cell after uptake.

The transfection is obviously related to cell division (mitosis). However, it has recently been shown by Kirchenbuechler et al. ${ }^{55}$ that a transfection is also possible in non-dividing cells, but with lower efficiency and on a longer timescale. Dividing HeLa cells showed a protein expression $\sim 2-5 \mathrm{~h}$ after division, whereas nondividing cells needed much more time to show a protein expression (up to $30 \mathrm{~h}$ ). Lipofectamine was used for transfection. Durymanov et al. ${ }^{56}$ demonstrated that the protein expression started $\sim 5 \mathrm{~h}$ after transfection of Cloudman $\$ 91$ melanoma cells with a polycationic formulation in post-mitotic cells and $\sim 15 \mathrm{~h}$ after transfection in non-divided cells. The probability for two transfected daughter cells was especially high in post-mitotic cells.

By comparison of Lipofectamine and and another liposomal formulation (DC-Chol/DOPE) for the transfection of CHO-K1 cells, Fiume et al. ${ }^{54}$ showed that Lipofectamine is especially successful to bring the plasmid DNA into both daughter cells after mitosis. This was related to the high number of DNA copies within the cell. Protein expression started $\sim 3 \mathrm{~h}$ after incubation with the transfection agents. Bishop et al. ${ }^{67}$ showed that the degradation of plasmid DNA inside a cell by nucleases is rapid and occurs with a half-life time of $\sim 2-3 \mathrm{~h}^{67}$ However, Cardarelli et al. ${ }^{68}$ followed the intracellular pathway of Lipofectamine and showed that the DNA remains protected after cellular uptake by avoiding lysosomal degradation. The uptake of the 'classical' transfection agent PEI was studied by live-cell imaging by Bausinger et al. ${ }^{69}$ with high-end optical methods, also during the individual transfection steps.

Calcium phosphate nanoparticles enter the cell by endocytosis ${ }^{70}$ and are then dissolved by acidification in the lysosome. ${ }^{46,71,72}$ From our results, it is clear that nanoparticles follow the same delivery pathway as liposomal formulations for transfection, but with a lower efficiency. This may be related to the endolysosomal pathway that can lead to an intracellular degradation of nucleic acids, ${ }^{46}$ which is avoided especially for Lipofectamine. ${ }^{68}$ The onset of the transfection and gene-silencing processes after incubation is comparable with Lipofectamine. The potential of nanoparticles clearly lies not in creating a transfection agent superior to Lipofectamine (which works very well) but to offer a means to transport different agents in one particle, for example, for vaccination ${ }^{73}$ or in vivo targeting. ${ }^{74}$

\section{CONCLUSIONS}

A number of conclusions can be drawn from these results. First, Lipofectamine is significantly more efficient than calcium phosphate nanoparticles, leading to almost complete transfection and gene silencing after $24-72 \mathrm{~h}$. The cell viability considerably decreases in the presence of Lipofectamine, but if the aim is a population of fully transfected cells, it is clearly superior to nanoparticles. Calcium phosphate nanoparticles lead to both lower and slower transfection and gene silencing, which starts $5 \mathrm{~h}$ after incubation, that is, later than with Lipofectamine. This may be because of the slower uptake and endolysosomal processing of nanoparticles compared to the liposomal Lipofectamine. It must also be noted that the concentration of nucleic acid in the cell culture medium was 10-20 times higher than with Lipofectamine. However, the cells are proliferating much more easily in the presence of nanoparticles compared to Lipofectamine. Together with the fact that the absolute number of transfected or silenced cells is comparable to Lipofectamine, this suggests a better applicability in vivo where it should lead to a reasonable degree of gene transfer together with better cytocompatibility. Calcium phosphate nanoparticles are therefore especially suitable as a tool to create multifunctional nanosystems that carry more than one biomolecule (for example, a nucleic acid together with an antigen and a targeting moiety).

\section{MATERIALS AND METHODS}

\section{Synthesis of calcium phosphate nanoparticles}

Calcium phosphate nanoparticles were precipitated from aqueous solutions of calcium nitrate $(6.25 \mathrm{~mm})$ and diammonium hydrogen phosphate 
CaP/DNA/CaP/PEI nanoparticles
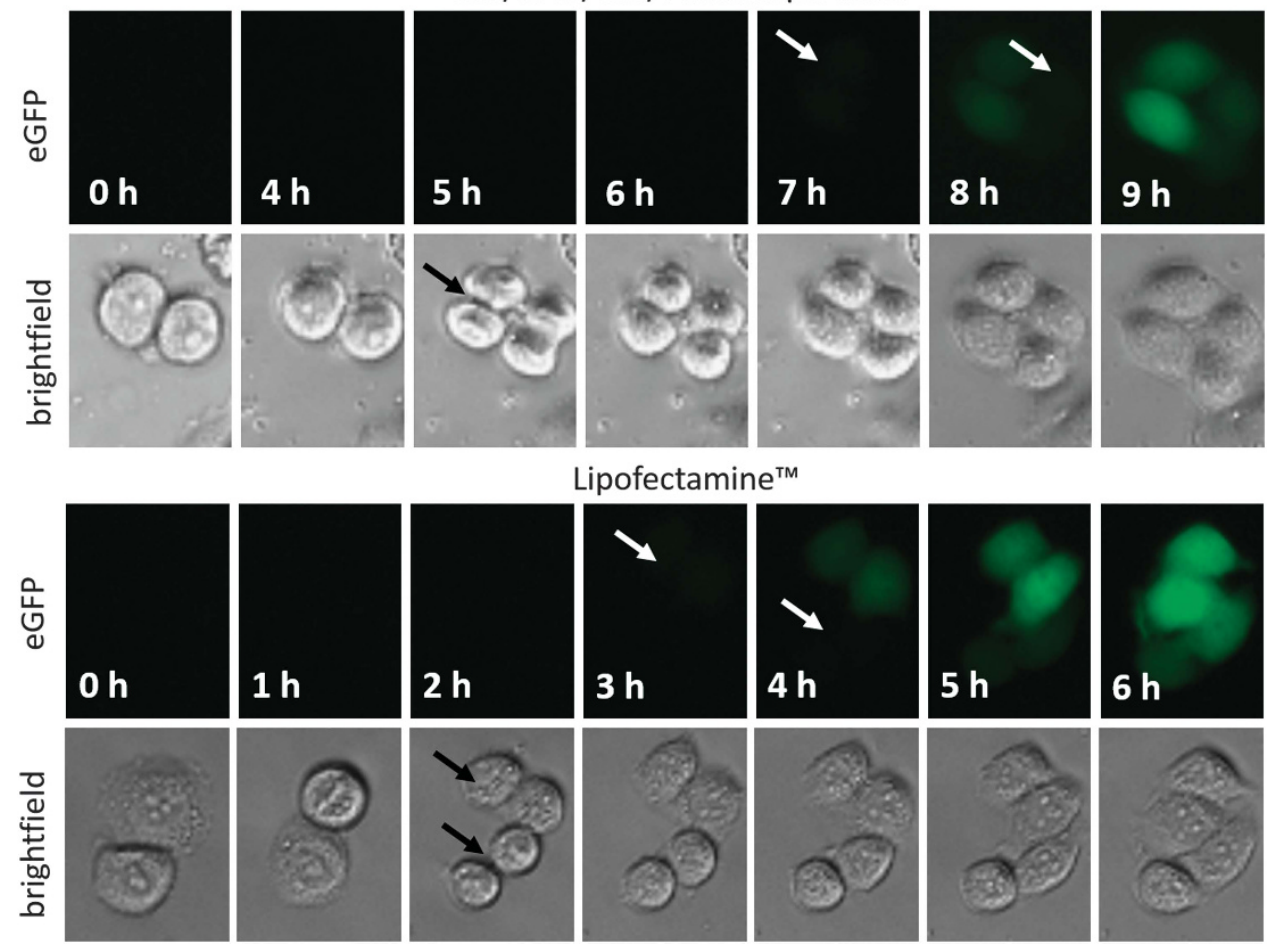

Figure 6. Live-cell imaging microscopy of HeLa cells during transfection with CaP/DNA/CaP/PEl nanoparticles and Lipofectamine. Black arrows indicate divided cells and white arrows indicate the visible fluorescence of the daughter cells.

(3.74 $\mathrm{mm})$ and then functionalized with DNA or siRNA $\left(1 \mathrm{~g} \mathrm{I}^{-1}\right)$ and PEI $\left(25 \mathrm{kDa}, 2 \mathrm{gl}^{-1}\right)$ as described earlier ${ }^{75}$ with the following modifications: CaP/DNA/CaP/PEI nanoparticles were separated from nonadsorbed molecules (including excess nucleic acid or PEI) by centrifugation $\left(5000 \mathrm{~g}, 4^{\circ} \mathrm{C}\right.$, $15 \mathrm{~min}$ ) and then dispersed in the half of the original volume of water by ultrasonication (UP50H, Hielscher, Teltow, Germany; Ultrasound Technology; sonotrode 2, cycle 0.8 , amplitude $80 \%, 10 \mathrm{~s})$. CaP/siRNA/CaP/PEI nanoparticles were isolated by centrifugation $\left(20000 \mathrm{~g}, 4^{\circ} \mathrm{C}, 15 \mathrm{~min}\right.$ ) and then dispersed in the original volume of water by ultrasonication with the same conditions.

Model DNA leading to the expression of eGFP (pcDNA3-eGFP) was used. For the gene-silencing experiments the eGFP-siRNA: sense, 5'-GCAA GCUGACCCUGAAGUUCAU-3'; antisense, 5'-AUGAACUUCAGGGUCAGC UUGC-3' (Invitrogen, Paisley, UK) was used. Lipofectamine 2000 was obtained from Life Technologies (Invitrogen, Carlsbad, CA, USA) and used according to the manufacturer's specifications.

\section{Characterization}

All nanoparticle dispersions were characterized by scanning electron microscopy (SEM), dynamic light scattering and nanoparticle tracking analysis. SEM was carried out with an ESEM Quanta 400 FEG instrument (FEl, Eindhoven, The Netherlands; gold-palladium [80:20]-sputtered samples). Size and zeta potential of the nanoparticles were determined by dynamic light scattering with a Zetasizer nanoseries instrument (Malvern Nano-ZS, Malvern, UK; laser: $\lambda=532 \mathrm{~nm}$ ) using the Smoluchowski approximation and by nanoparticle tracking analysis with a NanoSight LM10 Instrument (Malvern, UK). The calcium concentration was determined by atomic absorption spectroscopy (Thermo Electron Corporation, Thermo Fisher Scientific, Waltham, MA, USA; M-Series AA spectrometer) and then used to compute the calcium phosphate concentration in the nanoparticles dispersion.

The number of particles per volume was computed by taking the mass of calcium phosphate in the dispersion and assuming spherical nanoparticles with the diameter obtained by SEM:

$$
N(\mathrm{NP})=\frac{w(\mathrm{CaP})}{m(\mathrm{NP})}=\frac{3 w(\mathrm{CaP})}{4 \pi r(\mathrm{NP})^{3} \rho(\mathrm{CaP})}
$$

with $N(N P)$ the number of nanoparticles per $\mathrm{m}^{3}, w(\mathrm{CaP})$ the mass concentration of calcium phosphate in $\mathrm{kg} \mathrm{m}^{-3}$ (by assuming the stoichiometry of hydroxyapatite, $\left.\mathrm{Ca}_{5}\left(\mathrm{PO}_{4}\right)_{3} \mathrm{OH}\right), r(\mathrm{NP})$ the average radius of one nanoparticle from SEM, $m(\mathrm{NP})$ the mass of one nanoparticle and $\rho(\mathrm{CaP})$ the density of hydroxyapatite $\left(3140 \mathrm{~kg} \mathrm{~m}^{-3}\right)$.

The concentration of nucleic acid in the dispersion was determined by preparing the same particles with fluorescent Alexa555-labeled siRNA and quantitative analysis by UV-VIS spectroscopy after preparation of a calibration curve.

The concentration of PEI in the dispersion was determined by preparing the same particles with fluorescent FITC-labeled PEI and quantitative analysis by UV-VIS spectroscopy after preparation of a calibration curve.

All characterization data of the two nanoparticle stock solutions are listed in Table 1.

\section{Cell culture}

For the transfection experiments, we used HeLa cells (human transformed cervix epithelial cells). For the gene-silencing experiments, HeLa-eGFP cells were used that stably expressed eGFP. ${ }^{43}$ In all experiments, HeLa cells were cultured in DMEM, supplemented with $10 \%$ of fetal bovine serum, $100 \mathrm{U} \mathrm{ml}^{-1}$ penicillin, and $100 \mathrm{\mu g} \mathrm{ml}^{-1}$ streptomycin at $37^{\circ} \mathrm{C}$ in humidified atmosphere with $5 \% \mathrm{CO}_{2}$. HeLa-eGFP cells were cultured in DMEM, supplemented with $10 \%$ of fetal bovine serum and $50 \mathrm{\mu g} \mathrm{ml}^{-1}$ of the antibiotic Geneticin at $37{ }^{\circ} \mathrm{C}$ in humidified atmosphere with $5 \% \mathrm{CO}_{2}$.

Light and fluorescence microscopy were performed on a Keyence Biorevo BZ-9000 instrument (Osaka, Japan), both equipped with filters for TRITC (excitation: $540 \mathrm{~nm}$, emission: $605 \mathrm{~nm}$ ), GFP (excitation: $470 \mathrm{~nm}$, emission: $535 \mathrm{~nm}$ ) and 4,6-diamidino-2-phenylindole (excitation: $360 \mathrm{~nm}$, emission: $460 \mathrm{~nm}$ ) channels. The cells were stained with 4,6-diamidino-2phenylindole (nucleus; blue) and Cell mask (cell membrane; red) to indicate the cellular uptake of the nanoparticles.

Transfection with Lipofectamine was carried out according to the manufacturer's instructions. Fifty-microliter cell culture medium without fetal bovine serum were mixed with $2 \mu \mathrm{l}$ Lipofectamine. One-microgram DNA or siRNA was given to $50 \mu \mathrm{l}$ cell culture medium without fetal bovine serum. The two solutions were mixed and incubated for $20 \mathrm{~min}$ at room temperature. The mixture was then given to the cell culture at the appropriate dilution (1:7 for transfection and 1:5 for gene silencing). Transfection with nanoparticles was carried out by adding the appropriate amount of nanoparticle dispersion (stock solution as described in Table 1) to the cell culture medium and adding it to the well (dilution 1:7 for 
CaP/siRNA/CaP/PEI nanoparticles

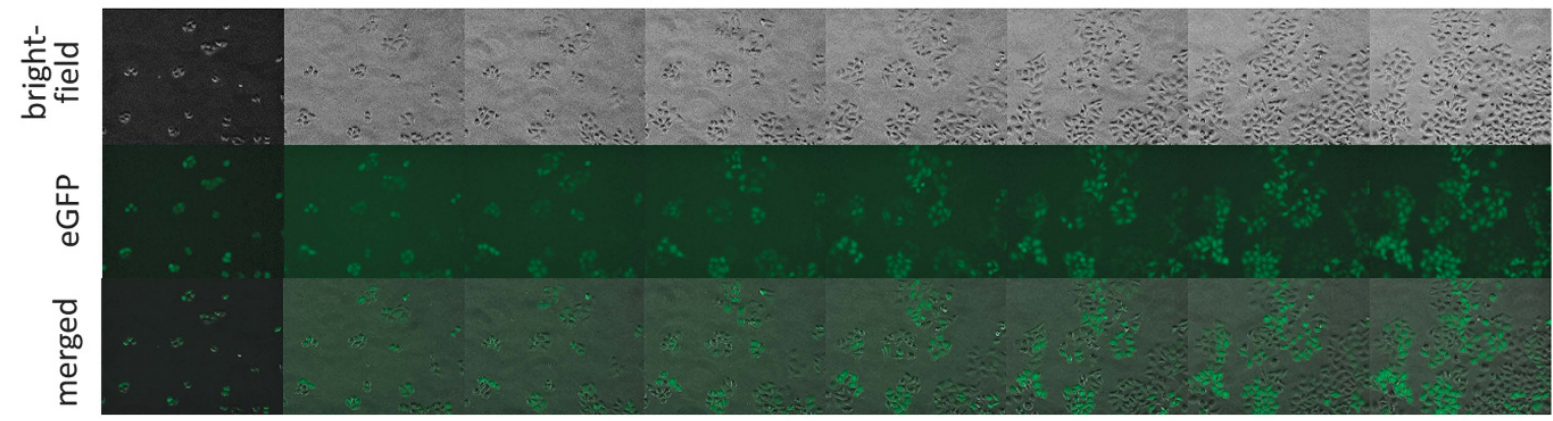

Lipofectamine $^{\mathrm{TM}}$

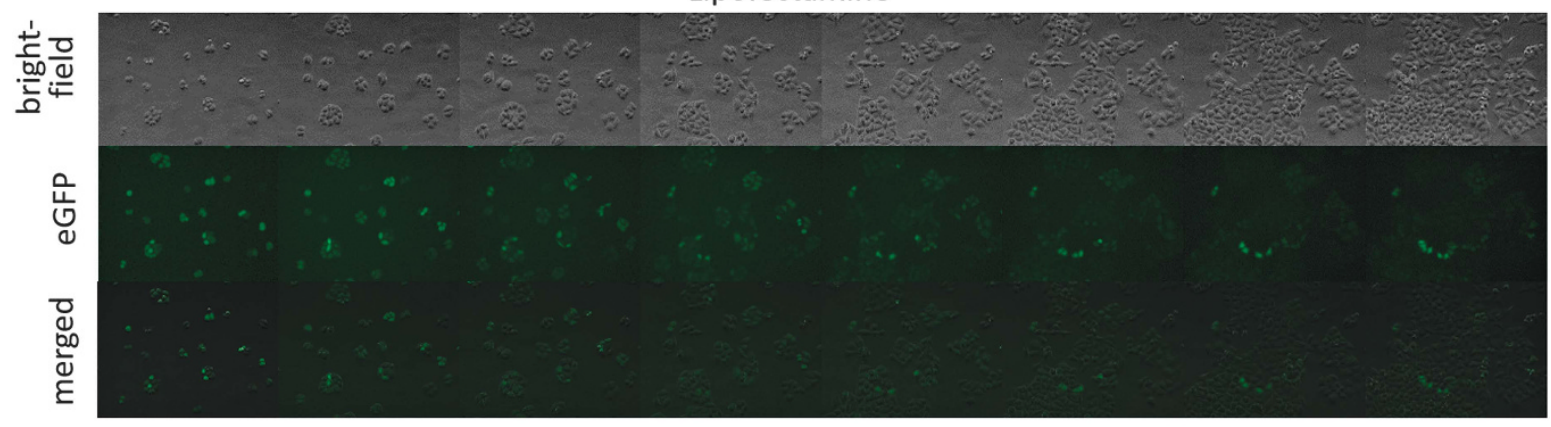

control

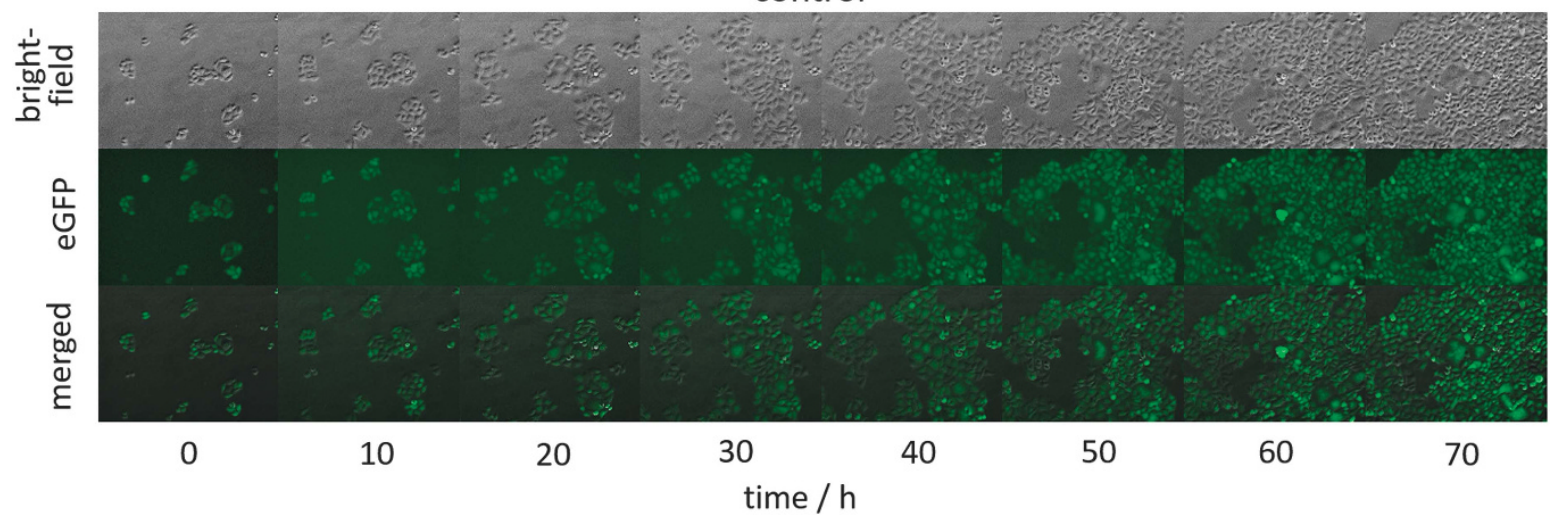

Figure 7. Live-cell imaging microscopy of HeLa-eGFP cells during gene silencing with CaP/siRNA/CaP/PEI nanoparticles and Lipofectamine. The control represents by untreated HeLa-eGFP cells.

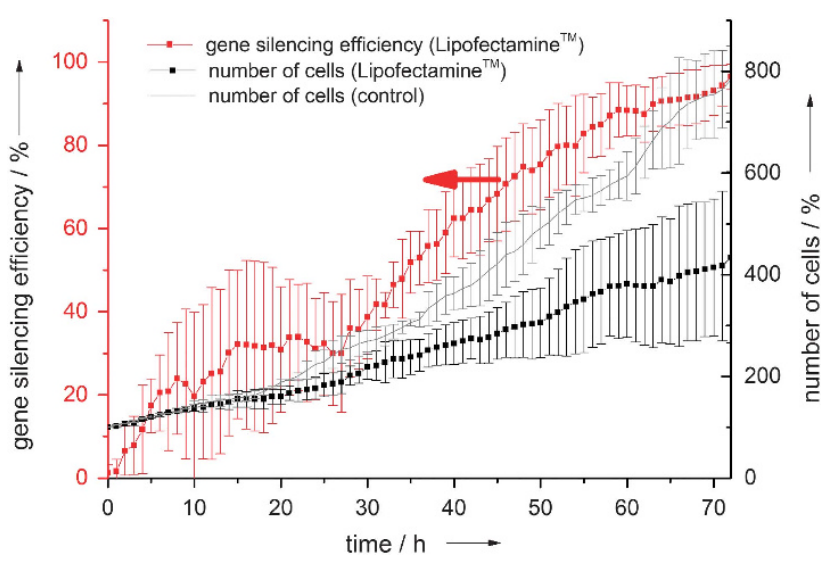

Figure 8. Gene silencing efficiency and relative number of HeLa-eGFP cells during the $72 \mathrm{~h}$ transfection with Lipofectamine. The relative number of the cells at the first time point $(0 \mathrm{~h})$ corresponds to $100 \%$. The control represents untreated HeLa-eGFP cells.

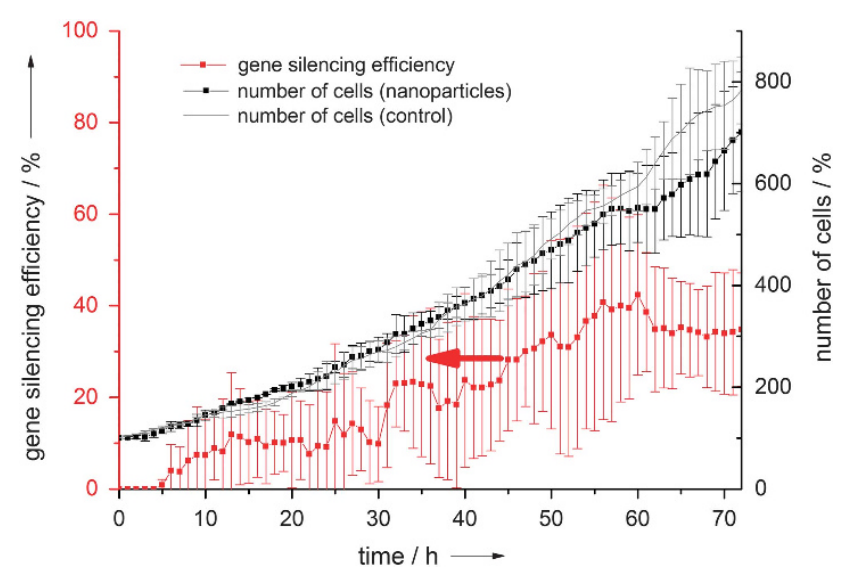

Figure 9. Gene-silencing efficiency and relative number of HeLa-eGFP cells during the $72 \mathrm{~h}$ transfection with $\mathrm{CaP} /$ siRNA/CaP/PEI nanoparticles. The relative number of the cells at the first time point $(0 \mathrm{~h})$ corresponds to $100 \%$. The control represents untreated HeLa-eGFP cells. 
transfection and 1:5 for gene silencing). The concentration of nanoparticles was selected according to earlier experiments. ${ }^{76}$

Live-cell imaging was performed with an INUG2EF-KI4 incubation chamber (TokaiHit, Keyence, Mechelen, Belgium), coupled to the Keyence microscope. The instrument was controlled by the BZ-II-Viewer software of the microscope (Keyence, Osaka, Japan). For transfection, $1.5 \times 10^{4}$ cells $\mathrm{cm}^{-2}$ were cultivated in each well of a four-well chamber. For gene silencing, $1.4 \times 10^{4}$ cells $\mathrm{cm}^{-2}$ were cultivated in each well of an eight-well chamber. After cultivation for $24 \mathrm{~h}$, transfection or gene silencing was started by adding Lipofectamine or nanoparticles. Untreated cells served as control. The recording time started immediately after incubation.

Images were taken every hour with the following parameters: $\times 20$ objective, recording time $1 / 20 \mathrm{~s}$ (FITC filter) and $1 / 7 \mathrm{~s}$ (phase contrast), four images at different points of the sample. For gene silencing, the recording time for phase contrast was $1 / 35 \mathrm{~s}$. After $7 \mathrm{~h}$, the cell culture medium was replaced by fresh medium.

The transfection efficiency was determined microscopically by counting green cells and colorless cells. ${ }^{46}$ The gene-silencing efficiency was determined in the same way by comparing green fluorescent and silenced cells. ${ }^{77}$ Four images at each time point were taken and individually analyzed for cells (at least 100 cells per image). The error bars given in the graphs indicate s.d.'s. The analyses were carried out by an independent person who was not informed before about the nature of the experiment (that is, whether the images resulted from control cells of transfected cells).

Microscopic image analysis has been shown to be an efficient method to determine transfection efficiencies, although the results typically differ from fluorescence-activated cell sorting and quantitative PCR analyses. ${ }^{77}$ This is because of the different probed features in the cell (protein fluorescence versus mRNA).

\section{CONFLICT OF INTEREST}

The authors declare no conflict of interest.

\section{ACKNOWLEDGEMENTS}

We are grateful to the Deutsche Forschungsgemeinschaft (DFG) for generous funding within the collaborative research center CRC/SFB 1093: Supramolecular Chemistry on Proteins.

\section{REFERENCES}

1 Tarassoli P, Khan WS, Hughes A, Heidari N. A review of techniques for gene therapy in bone healing. Curr Stem Cell Res Ther 2013; 8: 201-209.

2 Mazid R, Tan XM, Danquah KM. Molecular delivery of plasmids for genetic vaccination. Curr Pharm Biotechnol 2013; 14: 615-622.

3 Guo X, Huang L. Recent advances in nonviral vectors for gene delivery. Acc Chem Res 2012; 45: 971-979.

4 Danhier F, Ansorena E, Silva JM, Coco R, Le BA, Preat V. PLGA-based nanoparticles: an overview of biomedical applications. J Control Release 2012; 161: 505-522.

5 Pérez-Martínez F, Guerra J, Posadas I, Ceña V. Barriers to non-viral vector-mediated gene delivery in the nervous system. Pharm Res 2011; 28: 1843-1858.

6 Wang J, Lu Z, Wientjes MG, Au JLS. Delivery of siRNA therapeutics: barriers and carriers. AAPS J 2010; 12: 492-503.

7 Pichon C, Billiet L, Midoux P. Chemical vectors for gene delivery: uptake and intracellular trafficking. Curr Opin Biotechnol 2010; 21: 640-645.

8 Reischl D, Zimmer A. Drug delivery of siRNA therapeutics: potentials and limits of nanosystems. Nanomedicine 2009; 5: 8-20.

9 Nguyen DN, Green JJ, Chan JM, Langer R, Anderson DG. Polymeric materials for gene delivery and DNA vaccination. Adv Mater 2009; 21: 847-867.

10 Castanotto D, Rossi JJ. The promises and pitfalls of RNA-interference-based therapeutics. Nature 2009; 457: 426-433.

11 Sokolova V, Epple M. Inorganic nanoparticles as carriers of nucleic acids into cells. Angew Chem Int Ed 2008; 47: 1382-1395.

12 Paganin-Gioanni A, Bellard E, Escoffre JM, Rols MP, Teissie J, Golzio M. Direct visualization at the single-cell level of siRNA electrotransfer into cancer cells. Proc Natl Acad Sci USA 2011; 108: 10443-10447.

13 Kurreck J. RNA Interference: from basic research to therapeutic applications. Angew Chem Int Ed 2009; 48: 1378-1398.

14 Dzięgiel N. Nanoparticles as a tool for transfection and transgenesis - a review. Ann Animals Sci 2016; 16: 53-64.

15 Cortesi R, Campioni M, Ravani L, Drechsler M, Pinotti M, Esposito E. Cationic lipid nanosystems as carriers for nucleic acids. N Biotechnol 2014; 31: 44-54.
16 McNamara K, Tofail SA. Nanosystems: the use of nanoalloys, metallic, bimetallic, and magnetic nanoparticles in biomedical applications. Phys Chem Chem Phys 2015; 17: 27981-27995.

17 Liang H, Zhang XB, Lv YF, Gong L, Wang RW, Zhu XY et al. Functional DNA-containing nanomaterials: Cellular applications in biosensing, imaging, and targeted therapy. Acc Chem Res 2014; 47: 1891-1901.

18 Hu C, Peng Q, Chen F, Zhong Z, Zhuo R. Low molecular weight polyethylenimine conjugated gold nanoparticles as efficient gene vectors. Bioconjugate Chem 2010; 21: 836-843.

19 Han G, Ghosh P, Rotello VM. Multi-functional gold nanoparticles for drug delivery. Adv Exp Med Biol 2007; 620: 48-56.

20 Kim ST, Chompoosor A, Yeh YC, Agasti SS, Solfiell DJ, Rotello VM. Dendronized gold nanoparticles for siRNA delivery. Small 2012; 8: 3253-3256.

21 Arsianti M, Lim M, Marquis CP, Amal R. Polyethylenimine-based magnetic iron-oxide vector: the effect of vector component assembly on cellular entry mechanism, intracellular localization, and cellular viability. Biomacromolecules 2010; 11: 2521-2531.

22 Vallet-Regi M, Colilla M, Gonzalez B. Medical applications of organic-inorganic hybrid materials within the field of silica-based bioceramics. Chem Soc Rev 2011; 40: 596-607.

23 Kesharwani P, Gajbhiye V, Jain NK. A review of nanocarriers for the delivery of small interfering RNA. Biomaterials 2012; 33: 7138-7150.

24 Doerdelmann G, Kozlova D, Epple M. A pH-sensitive poly(methyl methacrylate) copolymer for efficient drug and gene delivery across the cell membrane. J Mater Chem B 2014; 2: 7123-7131.

$25 \mathrm{Hsu}$ CY, Uludag H. Cellular uptake pathways of lipid-modified cationic polymers in gene delivery to primary cells. Biomaterials 2012; 33: 7834-7848.

26 Maitra A. Calcium-phosphate nanoparticles: second-generation nonviral vectors in gene therapy. Expert Rev Mol Diagn 2005; 5: 893-905

27 Graham FL, van der Eb AJ. A new technique for the assay of infectivity of human adenovirus 5 DNA. Virology 1973; 52: 456-467.

28 Ito T, Koyama Y, Otsuka M. Preparation of calcium phosphate nanocapsule including deoxyribonucleic acid-polyethyleneimine-hyaluronic acid ternary complex for durable gene delivery. J Pharm Sci 2014; 103: 179-184.

29 Sahdev P, Podaralla S, Kaushik RS, Perumal O. Calcium phosphate nanoparticles for transcutaneous vaccine delivery. J Biomed Nanotechnol 2013; 1: 132-141.

30 Mostaghaci B, Loretz B, Haberkorn R, Kickelbick G, Lehr CM. One-step synthesis of nanosized and stable amino-functionalized calcium phosphate particles for DNA transfection. Chem Mater 2013; 25: 3667-3674.

31 Tang J, Chen JY, Liu J, Luo M, Wang YJ, Wei XW et al. Calcium phosphate embedded PLGA nanoparticles: A promising gene delivery vector with high gene loading and transfection efficiency. Int J Pharm 2012; 431: 210-221.

32 Lee D, Upadhye K, Kumta PN. Nano-sized calcium phosphate (CaP) carriers for non-viral gene delivery. Mater Sci Eng B 2012; 177: 289-302.

33 Uskokovic V, Uskokovic DP. Nanosized hydroxyapatite and other calcium phosphates: chemistry of formation and application as drug and gene delivery agents. J Biomed Mat Res B 2011; 96: 152-191.

34 Tabakovic A, Kester M, Adair JH. Calcium phosphate-based composite nanoparticles in bioimaging and therapeutic delivery applications. WIREs Nanomed Nanobiotechnol 2011; 4: 96-112.

35 Cao X, Deng W, Wei Y, Su W, Yang Y, Wei Y et al. Encapsulation of plasmid DNA in calcium phosphate nanoparticles: stem cell uptake and gene transfer efficiency. Int J Nanomed 2011; 6: 3335-3349.

36 Epple M, Ganesan K, Heumann R, Klesing J, Kovtun A, Neumann S et al. Application of calcium phosphate nanoparticles in biomedicine. J Mater Chem 2010; 20: 18-23.

37 Morgan TT, Muddana HS, Altinoglu El, Rouse SM, Tabakovic A, Tabouillot T et al. Encapsulation of organic molecules in calcium phosphate nanocomposite particles for intracellular imaging and drug delivery. Nano Lett 2008; 8: 4108-4115.

38 Kester M, Heakal Y, Fox T, Sharma A, Robertson GP, Morgan TT et al. Calcium phosphate nanocomposite particles for in vitro imaging and encapsulated chemotherapeutic drug delivery to cancer cells. Nano Lett 2008; 8: 4116-4121.

39 Antinoglu El, Russin TJ, Kaiser JM, Barth BM, Eklund PC, Kester M et al. Near-infrared emitting fluorophore-doped calcium phosphate nanoparticles for in vivo imaging of human breast cancer. ACS Nano 2008; 2: 2075-2084.

40 Olton D, Li J, Wilson ME, Rogers T, Close J, Huang L et al. Nanostructured calcium phosphates (NanoCaPs) for non-viral gene delivery: Influence of the synthesis parameters on transfection efficiency. Biomaterials 2007; 28: 1267-1279.

41 Xu ZP, Zeng QH, Lu GQ, Yu AB. Inorganic nanoparticles as carriers for efficient cellular delivery. Chem Eng Sci 2006; 61: 1027-1040.

42 Liu T, Tang A, Zhang GY, Chen YX, Zhang JY, Peng SS et al. Calcium phosphate nanoparticles as a novel nonviral vector for efficient transfection of DNA in cancer gene therapy. Cancer Biother Radiopharm 2005; 20: 141-149. 
43 Sokolova V, Kovtun A, Prymak O, Meyer-Zaika W, Kubareva EA, Romanova EA et al. Functionalisation of calcium phosphate nanoparticles by oligonucleotides and their application to gene silencing. J Mater Chem 2007; 17: 721-727.

44 Klesing J, Chernousova S, Kovtun A, Neumann S, Ruiz L, Gonzalez-Calbet JM et al. An injectable paste of calcium phosphate nanorods, functionalized with nucleic acids, for cell transfection and gene silencing. J Mater Chem 2010; 20: 6144-6148.

45 Kozlova D, Chernousova S, Knuschke T, Buer J, Westendorf AM, Epple M. Cell targeting by antibody-functionalized calcium phosphate nanoparticles. J Mater Chem 2012; 22: 396-404.

46 Neuhaus B, Tosun B, Rotan O, Frede A, Westendorf AM, Epple M. Nanoparticles as transfection agents: a comprehensive study with ten different cell lines. RSC Adv 2016; 6: 18102-18112.

47 Ewert K, Slack NL, Ahmad A, Evans HM, Lin AJ, Samuel CE et al. Cationic lipid-DNA complexes for gene therapy: understanding the relationship between complex structure and gene delivery pathways at the molecular level. Curr Med Chem 2004; 11: 133-149.

48 Dokka S, Toledo D, Shi X, Ye J, Rojanasakul Y. High-efficiency gene transfection of macrophages by lipoplexes. Int J Pharm 2000; 206: 97-104.

49 Byk T, Haddada H, Vainchenker W, Louache F. Lipofectamine and related cationic lipids strongly improve adenoviral infection efficiency of primitive human hematopoietic cells. Hum Gene Ther 1998; 9: 2493-2502.

50 Dalby B, Cates S, Harris A, Ohki EC, Tilkins ML, Price PJ et al. Advanced transfection with Lipofectamine 2000 reagent: primary neurons, siRNA, and high-throughput applications. Methods 2004; 33: 95-103.

51 Ming X, Sato K, Juliano RL. Unconventional internalization mechanisms underlying functional delivery of antisense oligonucleotides via cationic lipoplexes and polyplexes. J Control Release 2011; 153: 83-92.

52 Parhamifar L, Larsen AK, Hunter AC, Andresen TL, Moghimi SM. Polycation cytotoxicity: a delicate matter for nucleic acid therapy-focus on polyethylenimine. Soft Matter 2010; 6: 4001-4009.

53 Hakamada K, Miyake J. Evaluation method for gene transfection by using the period of onset of gene expression and cell division. J Biosci Bioeng 2012; 113: 124-127.

54 Fiume G, Di Rienzo C, Marchetti L, Pozzi D, Caracciolo G, Cardarelli F. Single-cell real-time imaging of transgene expression upon lipofection. Biochem Biophys Res Commun 2016; 474: 8-14.

55 Kirchenbuechler I, Kirchenbuechler D, Elbaum M. Correlation between cationic lipid-based transfection and cell division. Exp Cell Res 2016; 345: 1-5.

56 Durymanov MO, Yarutkin AV, Khramtsov YV, Rosenkranz AA, Sobolev AS. Live imaging of transgene expression in Cloudman $\$ 91$ melanoma cells after polyplexmediated gene delivery. J Control Release 2015; 215: 73-81.

57 Parhamifar L, Wu LP, Andersen H, Moghimi SM. Live-cell fluorescent microscopy platforms for real-time monitoring of polyplex-cell interaction: Basic guidelines. Methods 2014; 68: 300-307.

58 Sokolova V, Prymak O, Meyer-Zaika W, Cölfen $H$, Rehage $H$, Shukla A et al. Synthesis and characterisation of DNA-functionalised calcium phosphate nanoparticles. Mat-wiss u Werkstofftech 2006; 37: 441-445.

59 Kovtun A, Neumann S, Neumeier M, Urch H, Heumann R, Gepp MM et al. Nanoparticle-mediated gene transfer from electrophoretically coated metal surfaces. J Phys Chem B 2013; 117: 1550-1555.

60 Liu Z, Xiao Y, Chen W, Wang Y, Wang B, Wang G et al. Calcium phosphate nanoparticles primarily induce cell necrosis through lysosomal rupture: the origination of material cytotoxicity. J Mater Chem B 2014; 2: 3480-3489.

61 Dautova Y, Kozlova D, Skepper JN, Epple M, Bootman MD, Proudfoot D. Fetuin-A and albumin alter cytotoxic effects of calcium phosphate nanoparticles on human vascular smooth muscle cells. PLoS One 2014; 9: e97565.

62 Lange T, Schilling AF, Peters F, Mujas J, Wicklein D, Amling M. Size dependent induction of proinflammatory cytokines and cytotoxicity of particulate betatricalciumphosphate in vitro. Biomaterials 2011; 32: 4067-4075.
63 Lv HT, Zhang SB, Wang B, Cui SH, Yan J. Toxicity of cationic lipids and cationic polymers in gene delivery. J Control Rel 2006; 114: 100-109.

64 Paul A, Eun CJ, Song JM. Cytotoxicity mechanism of non-viral carriers polyethylenimine and poly-l-lysine using real time high-content cellular assay. Polymer 2014; 55: 5178-5188.

65 Bartlett DW, Davis ME. Insights into the kinetics of siRNA-mediated gene silencing from live-cell and live-animal bioluminescent imaging. Nucl Acids Res 2006; 34: 322-333.

66 Bartlett DW, Davis ME. Effect of siRNA nuclease stability on the in vitro and in vivo kinetics of siRNA-mediated gene silencing. Biotechnol Bioeng 2007; 97: 909-921.

67 Bishop CJ, Majewski RL, Guiriba TRM, Wilson DR, Bhise NS, Quinones-Hinojosa A et al. Quantification of cellular and nuclear uptake rates of polymeric gene delivery nanoparticles and DNA plasmids via flow cytometry. Acta Biomater 2016; 37: 120-130.

68 Cardarelli F, Digiacomo L, Marchini C, Amici A, Salomone F, Fiume G et al The intracellular trafficking mechanism of Lipofectamine-based transfection reagents and its implication for gene delivery. Sci Rep 2016; 6: 25879.

69 Bausinger R, von Gersdorff K, Braeckmans K, Ogris M, Wagner E, Bräuchle C et al. The transport of nanosized gene carriers unraveled by live-cell imaging. Angew Chem 2006; 118: 1598-1602.

70 Sokolova V, Kozlova D, Knuschke T, Buer J, Westendorf AM, Epple M. Mechanism of the uptake of cationic and anionic calcium phosphate nanoparticles by cells. Acta Biomater 2013; 9: 7527-7535.

71 Neumann S, Kovtun A, Dietzel ID, Epple M, Heumann R. The use of size-defined DNA-functionalized calcium phosphate nanoparticles to minimise intracellular calcium disturbance during transfection. Biomaterials 2009; 30: 6794-6802.

72 Ewence AE, Bootman M, Roderick HL, Skepper JN, McCarthy G, Epple M et al. Calcium phosphate crystals induce cell death in human vascular smooth muscle cells - a potential mechanism in atherosclerotic plaque destabilization. Circ Res 2008; 103: e28-e32.

73 Knuschke T, Rotan O, Bayer W, Sokolova V, Hansen W, Sparwasser T et al. Combination of nanoparticle-based therapeutic vaccination and transient ablation of regulatory $\mathrm{T}$ cells enhances anti-viral immunity during chronic retroviral infection. Retrovirology 2016; 13: 24.

74 Haedicke K, Kozlova D, Gräfe S, Teichgräber U, Epple M, Hilger I. Multifunctional calcium phosphate nanoparticles for combining near-infrared fluorescence imaging and photodynamic therapy. Acta Biomater 2015; 14: 197-207.

75 Sokolova V, Neumann S, Kovtun A, Chernousova S, Heumann R, Epple M. An outer shell of positively charged poly(ethyleneimine) strongly increases the transfection efficiency of calcium phosphate-DNA nanoparticles. J Mater Sci 2010; 45: 4952-4957.

76 Sokolova V, Radtke I, Heumann R, Epple M. Effective transfection of cells with multi-shell calcium phosphate-DNA nanoparticles. Biomaterials 2006; 27: 3147-3153.

77 Neuhaus B, Frede A, Westendorf AM, Epple M. Gene silencing of the pro-inflammatory cytokine TNF-alpha with siRNA delivered by calcium phosphate nanoparticles, quantified by different methods. J Mater Chem B 2015; 3: 7186-7193.

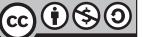

This work is licensed under a Creative Commons AttributionNonCommercial-ShareAlike 4.0 International License. The images or other third party material in this article are included in the article's Creative Commons license, unless indicated otherwise in the credit line; if the material is not included under the Creative Commons license, users will need to obtain permission from the license holder to reproduce the material. To view a copy of this license, visit http:// creativecommons.org/licenses/by-nc-sa/4.0/

(c) The Author(s) 2017 